\title{
FAKTOR-FAKTOR YANG MEMPENGARUHI PILIHAN KONSUMEN TERHADAP SALON YAYU DI MASAMBA KABUPATEN LUWU UTARA
}

\author{
NURMI, ABU BAKAR Q, HAPID
}

\begin{abstract}
ABSTRAK
Penelitian ini bertujuan untuk mengetahui dan menganalisis faktor-faktor yang mempengaruhi pilihan konsumen pada Salon Yayu di Masamba. Salon kecantikan tidak hanya menawarkan jasa kecantikan, tetapi juga hal-hal lain seperti, perlengkapan pengantin dan produk-produk lain. Faktor-faktor tersebut adalah nilai keunggulan bagi salon untuk bersaing dan menyediakan sarana yang dapat memenuhi kebutuhan bagi pelanggannya.

Metode penelitian yang digunakan yaitu metode penelitian survey. Penelitian ini dilakukan dengan mengambil sampel dari Salon Yayu di Masamba, dengan jumlah sampel sebanyak 100 responden dari jumlah populasi. Data primer yang diambil dari responden dengan kuesioner selanjutnya diolah dengan teknik Deaskriptif.

Hasil penelitian ini menunjukkan bahwa dengan adanya pelayanan, fasilitas, kenyamanan dan lokasi yang strategis akan menjadi faktor untuk mempengaruhi konsumen memilih salon. Selain itu, dapat menjadi nilai keunggulan bagi salon untuk bersaing dan menyediakan sarana yag dapat memenuhi kebutuhan bagi pelanggannya.

kesimpulannya bahwa besar faktor fasilitas, kenyamanan dan lokasi mempengaruhi pilihan konsumen pada Salon Yayu di Masamba Kabupaten Luwu Utara, sehingga di sarankan agar fasilitas, kenyamanan, dan lokasi yang strategis lebih diperhatikan dan dijaga karena faktor tersebut menentukan konsumen memilih Salon Yayu.
\end{abstract}

Kata kunci: Faktor Fasilitas, Faktor Kenyamanan, Faktor Lokasi, dan Pilihan Konsumen 


\section{Pendahuluan}

\section{Latar Belakang}

Salon kecantikan tidak hanya menawarkan jasa kecantikan, tetapi juga hal-hal lain seperti, perlengkapan pengantin dan produk-produk lain. Faktor-faktor tersebut adalah nilai keunggulan bagi salon untuk bersaing dan menyediakan sarana yang dapat memenuhi kebutuhan bagi pelanggannya.

Demikian juga dengan penentuan lokasi strategis, seperti letak di pusat kota atau perbelanjaan menjadi tempat favorit pengunjung yang berdomisili di kota-kota besar. Pelayanan dalam salon seperti; perawatan rambut serta jari-jari tangan dan kaki yang merupakan variasi pilihan bagi konsumen. Dalam menuangkan konsepkonsep yang ditawarkan, pengelola salon selalu menentukan beberapa gaya mode ke depan. Konsep-konsep dibuat sesuai dengan tren pusat kecantikan yang merupakan fenomena global, seperti yang ada di kota-kota besar.

Suasana salon yang tenang, dengan kecepatan dan kecermatan pelayanan dari para profesional dan staf memberi kenyamanan dan keamanan para konsumen. Guna membuktikan apakah salon tersebut berhasil dapat dilihat dari bertambahnya jumlah pengunjung.

Konsumen adalah raja,karena konsumen merupakan salah satu elemen penting dalam sistem perekonomian modern. Sebaik apapun kualitas produk yang dihasilkan produsen dan sehebat apapu pelayanan yang akan diberikan produsen, barang dan jasa tersebut tidak akan dibeli oleh konsumen jika konsumen tidak membutuhkannya. Konsumen sebagai raja memiliki makna bahwa para produsen harus memahami kebutuha konsumen, keinginannya, dan harapannya.selain itu produsen hendaknya membuat barang dan jasa sesuai dengan kebutuhan konsumen tersebut. Masalah penelitian ini adalah seberapa besar faktor fasilitas, kenyamanan dan lokasi mempengaruhi pilihan konsumen pada Salon Yayu di Masamba Kabupaten Luwu Utara. Tujuan penelitian ini adalah untuk mengetahui dan menganalisis faktor-faktor yang mempengaruhi pilihan konsumen pada Salon Yayu di Masamba.

\section{Metode Penelitian}

Tempat dan Waktu Penelitian

Penelitian ini dilakukan pada bulan april-juni 2010, yang berlokasi di kota Masamba, tepatnya pada Salon Yayu.

Jenis dan Sumber Data

1. Data Primer, yaitu data yang diperoleh secara langsung dari sumbernya, diamati dan dicatat oleh peneliti.

2. Data Sekunder, yaitu data yang bukan diusahakan sendiri oleh peneliti, melainkan data yang sudah tersedia dan peneliti tinggal mengutip. 
Populasi dan Sampel

Populasi yang ada dalam penelitian ini seluruh pelanggan/konsumen pada Salaon Yayu selama tiga bulan terakhir, sedangkan sampel sebanyak 100 responen dari jumlah populasi.

\section{Metode Pengumpulan Data}

Metode pengumpulan data yang digunakan adalah: (a) Penelitian lapangan (Field Research); Adalah penelitian yang dilakukan secara langsung pada objeknya. Kegiatan ini dilakukan agar peneliti dapat mengumpulkan data yang dibutuhkan secara langsung, (b) Wawancara; Metode pengumpulan data yang dilakukan dengan mengadakan tanya jawab kepada pihak-pihak yang dapat memberikan mengenai keterangan yang diperlukan,(c) Observasi; Yaitu metode pengumpulan data dengan cara mengadakan pengamatn dan pencatatan secara sistematis terhadap Salon Yayu, (d) Kuesioner; yaitu memberikan daftar pertanyaan pada responden untuk memperoleh data yang diperlukan, responden tinggal memilih beberapa alternatif jawaban.

\section{Metode Analisis Data}

Metode analisi yang digunakan adalah metode analisis Deskriptif. Analisa ini bertujuan untuk menjelaskan data hasil penelitian mengenai faktor-faktor yang mempengaruhi konsumen untuk memilih Salon Yayu.

\section{Hasil Penelitian Dan Pembahasan}

\section{Hasil Persamaan Deskriptif}

Responden yang menjadi sampel dalam penelitian ini sebanyak 100 responden adalah konsumen/pelanggan pada Salon Yayu. Gambaran mengenai responden yang menjadi sampel penelitian adalah sebagai berikut:

Jenis kelamin responden penelitian dapat dijelaskan pada tabel berikut ini:

Tabel 1

Jenis Kelamin Responden

Pelanggan Salon Yayu

\begin{tabular}{|l|l|l|}
\hline Jenis Kelamin & $\begin{array}{l}\text { Jumlah Responden } \\
(\text { Orang })\end{array}$ & Persentase \% \\
\hline Laki-laki & 15 & 0,15 \\
\hline Perempuan & 85 & 0,85 \\
\hline Jumlah & 100 & 100 \\
\hline
\end{tabular}

Sumber: Data Primer 2010

Tabel satu di atas menunjukkan bahwa sebagian besar responden yang menjawab kuesioner adalah responden yang berjenis kelamin laki-laki yaitu 
sebanyak 15 responden atau $(0,15 \%)$ dan sisanya adalah responden dengan jenis kelamin perempuan sebanyak 85 responden $(0,85 \%)$.

Sedangkan responden menurut usia dapat dilihat pada tabel berikut ini:

Tabel 2

Usia Responden

Pelanggan Salon Yayu

\begin{tabular}{|l|l|l|}
\hline Usia Responden & $\begin{array}{l}\text { Jumlah Responden } \\
\text { (orang) }\end{array}$ & Persentase (\%) \\
\hline Kurang dari 20 tahun & 35 & 0,35 \\
\hline Diatas 20 tahun & 65 & 0,65 \\
\hline jumlah & 100 & 100 \\
\hline
\end{tabular}

Sumber: Data Primer 2010

Dari tabel dua di atas dapat dijelaskan bahwa yang menjadi responden dalam penelitian ini sebagin besar adalah yang berusia lebih dari 20 tahun yaitu sebanyak 65 orang responden $(0,65 \%)$.

Untuk mengetahui jawaban responden dari hasil kuesioner yang terdiri dari variabel penelitian yakni fasilitas, kenyamanan dan variabel lokasi, maka dapat dijelaskan sebagai berikut:

Tabel 3

Tanggapan Responden

Terhadap Fasilitas Salon Yayu

\begin{tabular}{|l|l|l|}
\hline Tanggapan Responden & Frekuensi & Persentase (\%) \\
\hline Sangat Memotivasi & 22 & 0,22 \\
\hline Memotivasi & 75 & 0,75 \\
\hline Tidak Memotivasi & 2 & 0,02 \\
\hline Sangat Tidak Memotivasi & 1 & 0,01 \\
\hline jumlah & 100 & $100 \%$ \\
\hline
\end{tabular}

Sumber: Data Primer

Pada tabel tiga di atas menunjukkan bahwa sebanyak 75 responden $(0,75 \%)$ menyatakan fasilitas memotivasi, 22 responden $(0,22 \%)$ menyatakan sangat memotivasi, 2 responden $(0,02)$ menyatakan tidak memotivasi dan sebanyak 1 responden $(0,01 \%)$ menyatakan sangat tidak memotivasi. Dengan demikian maka dapat disimpulkan bahwa faktor fasilitas memotivasi konsumen dalam pengambilan keputusan memilih Salon Yayu.

Tabel 4

Tanggapan Responden

Terhadap Kenyamanan Pada Salon Yayu

\begin{tabular}{|l|l|l|}
\hline Tanggapan Responden & frekuensi & Persentase (\%) \\
\hline Sangat Memotivasi & 13 & 0,13 \\
\hline Memotivasi & 80 & 0,80 \\
\hline Tidak Memotivassi & 4 & 0,04 \\
\hline Sangat Tidak Memotivasi & 3 & 0,03 \\
\hline jumlah & 100 & 100 \\
\hline
\end{tabular}

Sumber: Data Primer 
Pada tabel empat di atas menunjukkan bahwa sebanyak 80 responden $(0,80 \%)$ menyatakan kenyamanan memotivasi, 13 responden $(0,13 \%)$ menyatakan sangat memotivasi, 4 responden $(0,04 \%)$ menyatakan tidak memotivasi dan sebanyak 3 responden $(0,03 \%)$ menyatakan sangat tidak memotivasi. Dengan demikian maka dapat disimpulkan bahwa faktor kenyamanan memotivasi konsumen dalam pengambilan keputusan memilih Salon Yayu.

Tabel 5

Tanggapan Responden

Terhadap Lokasi Salon Yayu

\begin{tabular}{|l|l|l|}
\hline Tanggapan responden & frekuensi & Persentase (\%) \\
\hline Sangat Memotivasi & 15 & 0,15 \\
\hline memotovasi & 82 & 0,82 \\
\hline Tidak Memotivasi & 2 & 0,02 \\
\hline Sangat Tidak Memotivasi & 1 & 0,01 \\
\hline jumlah & 100 & 1,00 \\
\hline
\end{tabular}

Sumber: Data Primer

Pada tabel lima di atas menunjukkan bahwa sebanyak 82 responden $(0,82 \%)$ menyatakan bahwa faktor lokasi memotivasi, 15 responden $(0,15 \%)$ menyatakan sangat memotivasi, 2 responden $(0,02 \%)$ menyatakan tidak memotivasi dan sebanyak 1 responden $(0,01 \%)$ menyatakan sangat tidak memotivasi. Dengan demkian maka dapat disimpukan bahwa fktor lokasi memotivasi konsumen dalam pengambilan keputusan memilih Salon Yayu.

Adapun variabel yang diukur adalah fasilitas, kenyamananan dan variabel lokasi seperti pada tabel berikut:

Tabel 6

Variabel Yang Diukur

\begin{tabular}{|l|l|l|}
\hline Variabel & Frekuensi & Persentase (\%) \\
\hline Fasilitas & 75 & 0,75 \\
\hline Kenyamanan & 80 & 0,80 \\
\hline Lokasi & 82 & 0,82 \\
\hline Jumlah & 100 & 1,00 \\
\hline
\end{tabular}

Sumber: Data Primer

Pada tabel enam di atas dapat disimpulkan bahwa faktor fasilitas memotivasi konsumen memilih Salon Yayu sebanyak 75 orang atau 0,75\%, faktor kenyamanan sebanyak 80 orang atau $0,80 \%$ dan faktor lokasi sebanyak 82 orang atau $0,82 \%$. Dari ketiga faktor yang diukur faktor lokasi yang paling dominan berpengarunh terhadap pemilihan Salon Yayu.

\section{Penutup}

Kesimpulan penelitian ini adalah bahwa besar faktor fasilitas, kenyamanan dan lokasi mempengaruhi pilihan konsumen pada Salon Yayu di Masamba Kabupaten Luwu Utara. Adapun saran dari penelitian ini adalah: (a) Agar fasilitas yang dimiliki 
pada Salon Yayu hendaknya tetap dipelihara dan dilengkapi terus, (b) Agar faktor kenyamanan lebih diutamakan dalam pelayanan konsumen, (c) Hendaknya lokasi atau tempat Salon Yayu di tempatkan pada lokasi yang strategi, karena faktor lokasi paling menentukan konsumen memilih Salon Yayu sesuai dengan hasil jawaban responden melalui kuesioner.

\section{DAFTAR PUSTAKA}

Ahmad Batinggi, 1999. Manajerial Pelayanan Umum. Universitas Terbuka, Jakarta. Basu Swasta dan Handoko, 2000. Dasar-dasar Manajemen (terjemahan), Edisi kelima, Jakarta. Aksara Baru.

Ciptono F, 1997. Prinsip-prinsip Total Quality Service. Andi Offset. Yogyakarta.

Hasan, Iqbal. 2002. Pokok-pokok Materi Statistik II: Statistik Inferensial. Penerbit Bumi Aksara. Jakarta.

Jasfar, Farida. 2005. Manajemen Jasa: pendekatan Terpadu. Bogor: Ghalia.

Kotler, Philip dan AB. Susanto. 2001. Manajemen pemasaran Indonesia. Buku 2. Salemba empat. Jakarta.

Kotler, Philip et al. 2001. Manajemen Pemasaran di Indonesia: Analisis Perencanaan, sImplementasi, dan Pengendalian Buku Dua. Jakarta: Salemba Empat.

Kotler, Philip. 2000. Manajemen Pemasaran. Jilid 2. Bumi Aksara. Jakarta.

Lupiyoadi, Rambat dan A. Hamdani. 2006. Manajemen Pemasaran Jasa. Jakarta: Salemba Empat.

Mowen. H. 2002. Perilaku Konsumen. Jilid I. Penerbit. Andi. Yogyakarta.

Munir, 2000. Manajemen Pelayanan Publik. Bina Aksara. Jakarta

Rismiati, Catur. Dan Bondan Sutrisno. 2001. Pemasaran Barang dan Jasa. Kanisius. Jakarta.

Sanusi, Anwar. 2003. Metodologi Penelitian Praktis Untuk Ilmu Sosial dan Ekonomi. Edisi Pertama. Cetakan Pertama. Penerbit Buntara Media. Malang. 
Nurmi et al -FAKTOR-FAKTOR YANG MEMPENGARUHI PILHAN KONSUMEN TERHADAP SALON....

Sugiyono. 2004. Metode Penelitian Bisnis. Cetakan Pertama. Penerbit CV. Alpha Beta. Bandung.

Sunarto. 2004. Prinsip-prinsip Pemasaran. Yogyakarta: penerbit AMUS.

Supranto, J. 1997. Metode Peramalan Kuantitatif Untuk Perencanaan Ekonomi dan Bisnis. Rineka Cipta. Jakarta.

The Liang Gie, 1981. Pengantar Organisasi dan Manajemen, Jakarta Balai Pustaka.

Ujang Suwarman, 2002. Perilaku Konsumen Teori dan Penerapannya Dalam Pemasaran, Penerbit Ghalia Indonesia, Jakarta.

Umar, Husein. 2002. Riset Pemasaran dan Perilaku Konsumen. Jakarta: Gramedia. 